UDK: 821.111(73)-32.09 Poe, E. A. 821.163.42-32.09 Matoš, A. G. Pregledni članak Primljen 13. II. 2019.

IVONA SMOLČIĆ

Rijeka

ivsmolcic@ffzg.hr

\title{
USPOREDNA ANALIZA PROZE EDGARA ALLANA POEA I ANTUNA GUSTAVA MATOŠA NA PRIMJERU NOVELA CRNI MAČAK I MIŠ
}

\section{Sažetak}

Antun Gustav Matoš jedan je od najvažnijih hrvatskih književnika moderne. Dio je svojega opusa izgradio pod utjecajem simbolističkoga pravca, a pritom je osobitu pažnju posvetio načinima razrješavanja ontološke krize. Uz prevladavajuće simbolističke motive dio njegovih novela sadržava i elemente fantastike. Edgar Allan Poe, pripadnik američkoga književnog romantizma, pisao je djela prožeta fantastičnim elementima s posebno naglašenim osjećajima jeze. Stoga njegovo književno stvaralaštvo poprima elemente simbolizma, zbog čega je kasnije prozvan pretečom toga pravca. Matoš je poznavao književno-teorijski rad Edgara Allana Poea. Utjecaj potonjega na djela hrvatskoga autora razvidan je u okviru simbolističke proze s elementima fantastike i groteske. Referiranjem na najvažnije teorijske postavke simbolizma i fantastične književnosti, kao i na osobitosti poetika dvaju autora, rad nastoji dokazati utjecaj Edgara Allana Poea na prozu Antuna Gustava Matoša. U tu će se svrhu komparacijski analizirati novele Miš (1899.) te Crni mačak (1849.) s obzirom na motivsku preokupaciju dvojice autora kao i na narativne cjeline tekstova.

Ključne riječi: simbolizam; fantastična proza; moderna; motivi; narativna struktura 


\section{Uvod}

Simbolizam kao književni pravac značajan je za dokazivanje međusobne povezanosti književnoga stvaralaštva Antuna Gustava Matoša i Edgara Allana Poea. Na temelju je toga moguće odrediti pojam ontološke krize koja se ocrtava kao osnova iz koje izvire cjelokupna poetika simbolizma. Iz procjepa sna i jave, kao i upadanjem u subjektivnost, dolazi do potrebe za pretvaranjem postojećih riječi u simbole kako bi se pokušalo opisati ono što je riječima nedostižno. Teorija fantastike prikazat će se kroz rad Cvetana Todorova. Na temelju toga objasnit će se određivanje žanra, podjela na podžanrove te fantastične teme i motivi. Posebno je važno spomenuti uzroke „zazornoga“ u književnosti, što će se u radu protumačiti pozivanjem na Sigmunda Freuda. Teorijski će se dio o simbolizmu primijeniti na interpretaciju djela Antuna Gustava Matoša (Miš). U tome je smislu nezaobilazan rad Dubravke Oraić Tolić koja se od svih autora najpodrobnije dotakla analize njegova proznog stvaralaštva. Za interpretaciju djela Edgara Allana Poea (Crni mačak) značajan je doprinos Sonje Bašić koja je ponudila detaljan pregled obilježja autorove proze.

\section{Teorijska razmatranja}

Naziv „moderna“ u povijesti se hrvatske književnosti odnosi na razdoblje prijelaza s 19. na 20. stoljeće, a obuhvaća otprilike ono što se unutar europskih književnih kretanja naziva epohom modernizma. Prema Bezić, modernizmom se naziva struja misli kojom se naglašava novitet, pa ono postaje oznakom osobitoga svjetonazorskog pravca europske književnosti (usp. Bezić, 1989: 159). Promjenu paradigme u razumijevanju umjetnosti valja razmatrati s obzirom na mijene koje su zahvatile čitavu Europu. Dominacija znanosti, tehnički napredak i industrijski razvoj uzrokovali su dekadentnost dijela građanstva. Prema Oraić Tolić sve to dovodi do ontološke krize koja podrazumijeva nov način shvaćanja i oblikovanja zbilje (usp. Oraić Tolić, 1996: 54). Autorica navodi i kako se ontološka kriza očitovala u umjetnosti doživljavanjem zbilje kao osobne estetske konstrukcije umjetnika. Sve je to uzrokovalo pojavu tzv. 
flanerističkoga subjektivizma, odnosno decentrirane svijesti oslabljena logičkog središta (usp. Oraić Tolić, 1996: 54, 55). Metodološki zaokret u hrvatskoj je situaciji obilježen konfrontacijom između „starih i mladih“. Tek se pojavom Antuna Gustava Matoša na domaćoj književnoj sceni omogućilo potpuno prihvaćanje novih ideja. U svijet književne produkcije ušao je novelom Moć savjesti (1892.) gdje njeguje poetiku kratke i fragmentalne priče. Takva zgusnuta kompozicija odgovara temeljnim obilježjima njegove poetike za koju će Oraić Tolić reći kako je determinirana dihotomijom između realnoga i nerealnoga s ciljem izazivanja začudnosti (usp. Oraić Tolić, 1996: 57). Njegove novele progovaraju o rijetkim, zanimljivim i neobičnim događajima uz doprinos ironije, humora i poetskih trenutaka. Likovi koje stvara odlikuju se psihološkim abnormalnostima, što nedvojbeno upućuje na one iz književnoga opusa Edgara Allana Poea. Valja istaći i prevladavajuću temu ljubavi u Matoševim djelima. Pritom je najčešće riječ o nedostižnu idealu koji, ili ostaje na razini neispunjene čežnje (Cvijet s raskršća) ili okončava bizarno (Miš, Balkon, Camao) (usp. Novak Prosperov, 2004: 159). Oraić Tolić tu Matoševu preokupaciju objašnjava stavom kako nedostižan ideal ljubavi i ljepote završava na način da se razriješi ontološka kriza. Bizaran je završetak djela posljedica stvarnosti razorene idealom (usp. Oraić Tolić, 1996: 64). Zagonetni događaji i fantastične teme posljedica su utjecaja gotskoga romana ili romana strave koji se počeo razvijati u epohi romantizma. Bitno je obilježje takvih narativa antitetičnost, pa sugeriraju supostojanje dobra i zla, racionalnoga i iracionalnoga. Fantastičnost ili, prema Todorovu, „žanr u nestajanju“ podrazumijeva pojave, stanja i događaje koji su u neskladu sa stvarnim, empirijskim i svakodnevnim svijetom (usp. Todorov, 1987: 46). Spomenuti autor elemente fantastičnosti odvaja u dvije skupine. Prvu čine djela koja prelaze u žanr „čudnoga“ jer su neprirodne pojave objašnjene. Drugu skupinu predstavljaju djela u kojima natprirodno ostaje prihvaćeno kao takvo (usp. Todorov, 1987: 46, 47). Todorov navodi i tri funkcije natprirodnoga, a to su pragmatična, sintaktična i semantička. Pragmatičnom se funkcijom čitatelja drži u neizvjesnosti kako bi se ostvario poseban dojam straha ili užasa. Sintaktička funkcija osigurava zgusnutu organizaciju zapleta 
kojima se također postiže neizvjesnost čitanja. Semantička omogućuje da opis fantastičnoga svijeta ne postoji izvan jezika (usp. Todorov, 1987: 96). Smatra se kako Poe noveli pristupa teoretski, što znači da stvara ljepotu izraza te prenosi vlastite ideje i raspoloženja na recepijenta (usp. Smith, 1970: 64). Svoja je osnovna razmišljanja naveo u kratkome eseju Filozofija kompozicije (1846.) gdje racionalistički i analitički pristupa procesu nastanka književnoga djela. Matoš se susreće s njegovim radom koji ga fascinira, pa reminiscencije na njega uvodi u mnoge svoje bilješke, eseje, kritike i feljtone. Prema Bašić, Matoš je često naglašavao njihove međusobne sličnosti poput protjerivanja, okruženosti svađom i polemikom te oskudice novca. Također smatra kako je u književnome radu Poe utjecao na Matoša odabirom tematskih preokupacija vezanih za ljubav i smrt. Uz to, razvidni su i poeovska atmosfera te ton, kao i inzistiranje na bizarnostima te izazivanju začudnosti. Teme fantastične književnosti uklapaju se u tipologiju problematike književnih tema uopće, ali zbog posebnosti toga žanra Todorov izdvaja dvije glavne skupine, odnosno „ja - teme“ i „ti - teme“. „Ja - teme“ temelje se na dvjema osnovnim skupinama natprirodnih činitelja. Riječ je o preobraženju i postojanju natprirodnih bića, čime se u narativnoj strukturi nadoknađuje nedostatak uzročnosti. Time se u djelu generira fantastično kao i dokidanje granica između stvarnoga i duhovnoga svijeta (usp. Todorov, 1987: 117). „Ti - teme“ Todorov usko veže za seksualnost. Prema njemu, natprirodno dolazi kako bi usmjerilo spolne nagone, a želja kao iskušenje u oblicima poput incesta, homoseksualizma, orgija, sadizma i nekrofilije. Subjekt u tome slučaju pokretački djeluje prema drugima te je aktivan, za razliku od subjekta kao pasivna promatrača koji je prisutan u „ja - temama“ (usp. Todorov, 1987: 142, 143). U okviru fantastične književnosti važno je spomenuti i pojam zazornosti. Lavkraft ustanovljuje sljedeće: „Priča je fantastična jednostavano onda kada čitalac duboko oseća stravu i užas, prisustvo neobičnih sila" (Lavkraft prema Todorov 1987: 39). Freud to tumači terminom Unheimliche koji označava užas, stravu, jezu, zazornost. Objašnjava ga kao sve ono što pripada iskustvu strašnoga, ali potječe od onoga poznatog i odavno bliskoga (usp. Freud, 2010: 8). Prema njemu, zazorno u književnosti obuhvaća strahove poput 
onoga od smrti, kastracije, zlih ljudi, padavice, ludila, brisanja granica između mašte i zbilje, nenamjernoga vraćanja istoga, dvojništva kao i strah od toga da subjekt bude živ zakopan (usp. Freud, 2010: 18-37). U simbolističkoj se umjetnosti „ja -teme“, karakteristične za fantastičnu književnost, preuzimaju i preoblikuju na način da se problematika podudarnosti čula produbljuje na problem pomicanja granica između sna i jave. Također, brisanje granica subjekta i objekta u simbolizmu uzrokuje potpunu prevlast subjekta te naglašavanje njegova individualizma. Willson objašnjava kako simbolizam premješta cjelokupno polje književnosti iz objektivnoga u subjektivni univerzum, a sve radi potrebe odvajanja subjekta od društva i stvarnosti (usp. Wilson, 1964: 218).

\section{Usporedna analiza novela Miš Antuna Gustava Matoša i Crni mačak Edgara Allana Poea}

\subsection{Podjela motiva i vrste motivacije u djelima}

Antun Gustav Matoš živio je i djelovao tijekom razdoblja moderne, pa većina njegovih djela nosi obilježja vladajuće epohe. U mnogima se uz simbolizam uočavaju i elementi fantastične književnosti. Za razliku od Matoša, Edgar Allan Poe stvarao je u vrijeme romantizma, obilježena gotskim romanima i fantastičnom književnošću. Njegovim opusom prevladava utjecaj fantastike uz razvidne elemente simbolizma. Matoševa novela Miš objavljena je kao dio zbirke Iverje 1899., dok je jedna od najpopularnijih Poeovih novela Crni mačak objavljena 1843. godine. Spomenuto Matoševo djelo Frangeš ubraja u svoj treći krug priča o „neobičnim, nerealnim i nevjerojatnim zgodama“ (Frangeš, 1974: 10). Prema klasifikaciji Dubravke Oraić Tolić, Miš je narativno tkivo s prevladavajućom simbolističkom poetikom, kod Matoša često prožetom fantastikom i groteskom (usp. Oraić Tolić, 1996: 57). S druge strane, Poeov Crni mačak dio je kruga grotesknih priča i arabeski (usp. Bašić, 1985: 8), odnosno prema Cunliffeovu nazivlju horor-priča (usp. Cunliffe, 1974: 74). Osnovna je preokupacija simbolista odbacivanje tradicionalnih vrijednosti i zaokupljenost subjekta sobom i svojim psihičkim procesima, 
što dovodi do pojave ranije spomenute ontološke krize. U skladu s tim glavni lik Matoševe novele rastrgan je između jave i sna, čime je pružen opis ljudske psihe. On odbacuje društvo te se povlači u samoću gdje kontrolu nad njim preuzimaju halucinacije. Osamljivanje je razvidno i u noveli Crni mačak gdje je glavni lik ljudski krug društva zamijenio životinjskim. To je dodatno naglašeno motivom zidova, pa postaje zarobljenikom vlastita bića. Bašić će reći kako on živi u moralno mrtvome prostoru te da za njega ne postoji mogućnost bijega od vlastitoga sebstva (usp. Bašić, 1985: 10, 11). U Matoševu je djelu stvarnost dehumanizirana, zato dolazi do onoga što Milanja naziva subjektovim bijegom od realiteta (usp. Milanja, 2010: 51). Obje novele tematiziraju smrt što se na Matoševu primjeru postavlja kao posljedica antagonizma između stvarnosti i mašte, dok je kod Poea također motivirana psihičkim stanjem književnoga subjekta. Obje novele naslovljene su prema glavnim simbolima djela. Miš predstavlja nečistu savjest glavnoga lika, stoga se zaključuje kako on grizodušje osjeća na nesvjesnoj razini. Mačak crne boje također simbolizira tamnu stranu ličnosti glavnoga protagonista. Ona se materijalizira u liku životinje zbog koje sam razotkriva grobnicu svoje supruge, koju je prethodno usmrtio. Prostorna je dimenzija kod Matoša raspršena, a jedini stalan prostor onaj je koji se odnosi na subjektove halucinacije. Protok vremena prikazan je sukcesivno, uz sporadičan retrospektivan element, što je, uz opisanu ambijentalnost, dodatan element simbolizma. Poe svojega glavnog lika smješta u zatvoreni prostor, a time odudara od konvencija književnoga stila koji teži otvorenosti. Odabir bizarnih tema u oba djela ovjerava prisutnost fantastičnih elemenata. Začudnost se u oba slučaja razrješava halucinacijama koje potvrđuju kako je riječ o posljedicama pomaknutih psihičkih procesa. Stoga obje novele pripadaju žanru „čisto čudnoga“. Novele su karakterizirane jednostavnom fabulom, a nedostatak je scenskoga efekta kompenziran uvođenjem motiva situacije, karakterizacije i djelovanja. Takva fabula postavlja zahtjev međusobnoga ulančavanja i spojenosti motiva kao najmanjih značenjskih jedinica. Pritom se distingviraju oni dinamički, kojima se ostvaruje pripovijedanje, i statični koji su u funkciji opisivanja (usp. Tomaševski, 1998: 98). Novela Miš naslovljena je prema jednomu 
od temeljnih motiva u djelu. Riječ je o dinamičkome motivu za koji se može tvrditi da objedinjuje značenje ljubavi i smrti. Miš je nadimak djevojke glavnoga protagonista Mihajla Milinovića. Ona počini samoubojstvo koje je posljedica njegova odbacivanja ideje da je oženi i prihvati njihovo zajedničko dijete. Nakon početnoga uživanja u životu Milinović zapada u psihički rastrojeno stanje koje mu se pogoršava zbog miševe prisutnosti u sobi gdje boravi. Naposljetku, tijekom jednoga od psihičkih napadaja upada u zamku postavljenu za životinju i od nje pogiba. Stoga se miš od početnoga sinonima za Ljubicu tijekom fabule preobražava u motiv ludila. Drugi je dinamički motiv Ljubičina trudnoća jer se njime osigurava fabularna uzročnost. Milinovićevo neprihvaćanje trudnoće Ljubicu navodi na samoubojstvo koje generira njegovo ludilo i halucinaciju. Potonje se također može poimati u svjetlu dinamičkih motiva jer su uzrok smrti glavnoga protagonista. Statički motivi ne utječu na radnju, ali su relevantni u kontekstu motivacije. To su: groblje, vjetar, kiša, oblaci, maj, proljeće, mjesečina, zvijezde, šara na plafonu, nerođeno dijete. Prema definiciji koju navodi Tomaševski motivacija je sustav postupaka koji opravdavaju uvođenje pojedinih motiva i njihovih kompleksa (usp. Tomaševski, 1998: 24). Ona može biti kompozicijska, realistička i umjetnička. Kompozicijska sadrži pojedine motive koji pripremaju čitatelja na završetak djela. Predstavlja karakteristične detalje koji se usklađuju s radnjom prema psihološkoj analogiji ili kontrastu (usp. Tomaševski, 1998: 24, 25). Većina se u djelu prisutnih statičkih motiva nalazi u ovoj skupini motivacije. Prema tome, šaru na plafonu valja razmatrati kao motiv koji čitatelja priprema na završetak radnje jer se njome simbolizira mrlja u dotadašnjemu bezbrižnom životu glavnoga lika. Važan je motiv i groblje koje se u djelu početno pojavljuje kao dio Ljubičina pisma Mihajlu: „Jutros bijesmo na groblju tvoje pokojne strine. Divno groblje! (...) Tu bih i ja htjela počinuti“" (Matoš, 1935: 104). Razvidno je kako njime Ljubica upozorava na dvostruku smrt koja će se uskoro pojaviti. Pojavljuje se i na samome kraju: „Sa njom ga sahrani na samotnom araberškom grolju pored svoje žene" (Matoš, 1935: 120). Stoga se motiv groblja na koncu ostvaruje kao posljednje počivalište obaju likova koji su se na taj način ponovno sjedinili. Važno je izdvojiti i motiv 
nerođenoga djeteta kojim se ocrtava Milinovićev stav prema Ljubičinoj trudnoći. Zanimljvo je da ga on nikad ne oslovljava leksemom dijete, nego se služi pogrdnim izrazima poput klupčić, nametljivac ili ulješčić. (Matoš, 1935: 100) Navedeno implicira njegovu distanciranost od čitave situacije kao i bijeg od stvarnosti. Motivi poput maja, proljeća, kiše i vjetra također su vezani za kompozicijsku motivaciju, a njihova je svrha detaljnije karakteriziranje radnje. Njihov je odnos moguće pratiti u okviru kontrasta između Ljubičine i Milinovićeve percepcije. Ljubica će reći: „Ovdje je prekrasno! (...) Oko mene cvati jorgovan. (...) Još me nijedno proljeće ne opijaše kao ovo“ (Matoš, 1935: 104). Mihajlo na njezinu zanesenost reagira riječima: „Sviđa ti se maj? Pa lijepo! Meni je proljeće dosadno kao sve..." (Matoš, 1935: 107) Razvidno je kako Ljubica svoje trenutno stanje promatra kroz vizuru buđenja novoga života, karakteristična za razdoblje proljeća, što Milinović nije kadar razabrati zbog vlastite naravi koja ga usmjerava isključivo na sebe sama. U skladu s tim on ističe motive kiše i vjetra jer iz njegova rakursa simboliziraju način na koji se sudbina odnosi prema njemu. Motivi mjeseca, zvijezda i oblaka dolaze kao posljedice subjektova psihičkog stanja, koji ih u skladu s tim doživljava kao dijelove golemoga miša koji ga uhodi: „Oblaci? Ne. To su gole crne i naborane mišje repine, pa zmijeski zvižde i skiću noćnijim zrakom. Zvijezde? Ne. To se užagriše zelenkasto i krvavo pakosne očice...." (Matoš, 1935: 115) Važno je spomenuti kako je kompozicija realistična jer se njome omogućuje čitateljevo prihvaćanje navedenih događaja kao stvarnih (usp. Tomaševski, 1998: 26). U kontekstu je promatranoga djela vjerodostojnost događaja iznimno važna jer novela dijelom pripada žanru fantastike. Stoga uporište u stvarnosti predstavljaju motivi trudnoće, sna i ludila. Tomašević ih naziva naziva običnima, ali onima koji dopuštaju mogućnost dvostruke interpretacije (usp. Tomaševski, 1998: 30). Stoga se halucinacijama ostvaruje vjerovanje u zahtjev za iluzijom koju pisac stvara. U djelu je razvidna i umjetnička motivacija što je postignuto motivom miša. Ta vrsta motivacije definirana je kao korištenje stvarnih motiva koji su, prema Tomaševskomu, „ukorijenjeni u pripovjednu konstrukciju te osvijetljeni s osobite strane" (usp. Tomaševski, 1998: 32). Dakle, miš isprva obilježava Ljubicu koju 
Milinović odmila tako oslovljava, dok se nakon njezine smrti pojavljuje kao stvarna životinja i nametljivac koji ga izluđuje. Tako inače uobičajen motiv postaje neobičnim, pa se ostvaruje preduvjet za djelomičnom pripadnosti pripovijetke žanru fantastike. U djelu su razvidni i kompleksi motiva u vidu navođenja pisaca (Leskovar, Jakšić, Preradović, Šenoa, Gjalski), referiranja na motiv lijepe žene (junonska leđa, snježan vrat, djevice, usne), motiva okultnoga (alkemija, astrologija, misticizam, kabalistika) i motiva bolesti (manija, agrofobija, katalepsija, hipohondrija). Lijepa se žena ovdje javlja kao subjektov nedostižni ideal i iluzija. Zanimljivo je kako Ljubica, kao izvor Milinovićeve nedaće, nije opisana kao ljepotica. Osim toga, svojom izvanbračnom trudnoćom ne predstavlja ni uzor ženske čednosti. Motivom bolesti duševnomu se stanju lika nastoji pridati stvarna dimenzija jer se psihički delirij pokušava razumski objasniti.

Glavni i ujedno dinamički motiv Poeove novele predstavlja crni mačak, pa je već s početka razvidna sličnost između obojice autora, a to je naslovljavanje djela prema glavnomu, napose pokretačkomu motivu. Drugi je dinamički motiv bolest alkoholizma zbog koje protagonist ispoljava agresiju prema supruzi i kućnim ljubimcima. To je ujedno i glavni uzročnik buđenja njegovih opsesija, pa se iščitava sličnost s Matoševim Milinovićem kod kojega je također prisutno stanje pomaknutoga doživljavanja stvarnosti. Statički su motivi: vatra, požar, jednooki mačak, mrlja u obliku vješala, zid i podrum. Glavnoga protagonista, nakon što objesi mačka Plutona o drvo, sustiže požar tijekom kojega gubi svoju imovinu. Motiv vatre koji se pojavljuje nakon ubojstva sugerira konačno uništenje preostale ljudskosti u njemu kao i prevladavanje maničnoga stanja, što je usporedivo s pustoši koja je ostala nakon vatrene stihije. Požar je povezan i s mrljom u obliku mačka s užetom oko vrata na jedinome očuvanom zidu izgorjele kuće. Njome se upućuje na nečistu savjest ubojice koji tu pojavu objašnjava mišlju kako je netko od susjeda ubacio mačka u kuću. Motiv se vješala može shvatiti i kao upozorenje na kaznu koja ga očekuje. Time se ovjerava postojanje kompozicijske motivacije u djelu jer navedeni motivi čine analogiju s psihičkim stanjem lika. Navedeno se može razmatrati u odnosu sa šarom na stropu na 
primjeru Matoševe novele jer obje sugeriraju kraj, pa predstavljaju jednu od poveznica između dvaju promatranih djela. Kompozicijska motivacija obuhvaća i motiv jednookoga mačka. Riječ je o Plutonu, kojemu je protagonist nasilno odstranio oko, i o novome mačku koji je s početka jednook. Time se u svijesti čitatelja intenzivira dojam strave jer se novoga ljubimca može sagledavati u svjetlu oživljenoga Plutona. Zidovi su također važan motiv pa njihovo urušavanje tijekom požara ukazuje na otkrivanje tajne koju skrivaju, a to je grobnica supruge koju je usmrtio. U realističku se motivaciju ubraja dinamički motiv bolesti alkoholizma, za koji sam pripovjedač kaže: „Naše je prijateljstvo trajalo tako nekoliko godina, tijekom kojih je moja opća ćud i značaj - djelovanjem onoga đavla Neumjerenosti u piću - pretrpjela (stid me je priznati) korjenitu promjenu nagore. Postajao sam iz dana u dan mrzovoljniji, razdražljiviji, bezobrazniji prema tuđim čuvstivima“ (Poe, 1985: 18). Time subjekt tumači svoju promjenu, osobito u kontekstu ljubavi prema životinjama. Motiv je dinamičan jer služi kao izravno opravdanje za pokretanje niza okrutnih događaja koji slijede. Motivacija koja se razabire u alkoholizmu realistična je jer čitatelj navedene događaje može prihvatiti kao stvarne sagledavajući ih iz prizme bolesti. Također, ostvaruje se i pripovjedačevom instancom u prvome licu. Time se djelo iznosi u obliku vlastita svjedočanstva, čime se povećava razina vjerodostojnosti narativa. S obzirom na to da je zadaća umjetničke motivacije pridati uobičajenim motivima inventivnu ulogu u djelu, motiv se crnoga mačka na Poevu primjeru također razrađuje na način da postaje nositeljem simboličkoga značenja. Glavni je lik isprva bio povezan s njime, ali napretkom njegova problema s alkoholom taj se odnos mijenja, pa se saznaje: „...čak i Pluton stade dolaziti u priliku da iskusi posljedice moje zle volje“ (Poe, 1985: 18). S obzirom na Plutonov povratak u obliku novoga ljubimca dolazi do zadovoljenja pravde jer se omogućuje da protagonista sustigne kazna zbog ubojstva koje je počinio. Mačak se tako može sagledavati kao izvor strave, a raspletom koji donosi postaje elementom čudnoga u djelu. 


\subsection{Narativne strukture novela}

Genettov termin dijegeza označava fabulu te, s obzirom na pripovjedačevu prisutnost unutar nje, distingvira ekstradijegetskoga i intradijegetskoga pripovjedača. Ovisno o svojemu odnosu prema događajima koje iznosi može biti heterodijegetski i homodijegetski. S obzirom na fokalizaciju razlikuju se tri vrste tekstova, odnosno nefokalizirani pripovjedni tekst ili tekst s nultom fokalizacijom, tekst s unutrašnjom fokalizacijom i tekst s vanjskom fokalizacijom (usp. Biti, 1992: 99). Novela Miš može se determinirati kao nefokalizirani tekst jer je riječ o klasičnome pripovjednom tkivu. Segmenti koji se odnose na stvarnost obilježeni su objektivnom točkom gledišta, dok tijekom Milinovićevih halucinacija pripovjedač zauzima poziciju istovjetnu s likom. To je razvidno tijekom sljedećega citata: „Pomalo je u sujevjeran. Crne slutnje, koje ga napostavahu u posljednje vrijeme nijesu se dakle izjalovile. I leže na divan, zadubivši se zlovoljno u šaru na plafonu“ (Matoš, 1935: 99). Stoga dolazi do unutrašnje fokalizacije za koju Barthers kaže kako je uvjetovana mogućnošću prepisivanja pripovjednoga segmenta u prvome licu, a da se pritom, osim gramatike, ne dogodi nikakva promjena diskursa (usp. Biti, 1992: 102). U noveli Crni mačak pripovjedač je prisutan kao lik u radnji. Iako su te dvije instance blisko povezane, ipak je riječ o nultoj fokalizaciji koja je dijelom unutrašnja. Prema Barthesu unutrašnja se fokalizacija u potpunosti ostvaruje samo unutrašnjim monologom (usp. Biti, 1992: 101), što na ovome primjeru izostaje. Pripovjedač nije sveznajuć, nego je informiran koliko i glavni lik, što je osobito razvidno tijekom njegovih filozofskih promišljanja: „A ipak, kao što sa siguran moja duša živi, tako vjerujem da je nastranost jedan od najiskonskijih poriva ljudskoga srca - jedna od onih nedjeljivih prvotnih čestica ili čuvstava koji usmjeravaju značaj čovjeka“ (Poe, 1985: 19). Psihološka stanja glavnoga lika prikazana su racionalno pa se dokazuje ranije spomenuta djelomična zastupljenost unutrašnje fokalizacije. „Pošto sam počinio ovo gnusno ubojstvo, smjesta sam se, savršeno promišljeno, dao na zadatak da sakrijem truplo. Znao sam da ga iz kuće ne mogu iznijeti, ni noću ni danju, a da se ne izložim opasnostima da me susjedi zapaze. Glavom su mi se rađale razne ideje“ (Poe, 1985: 22). Pripovijedanje u prvome licu 
indikativno je jer se pripovjedačevom instancom, kao svjedokom zbivanja, ovjerava vjerodostojnost fantastične dimenzije djela. Sintetiziranjem takva pripovijedanja i objektivna prikaza likova stanja autor stvara etički unakažen subjekt koji ne preuzima odgovornost za svoja djela. U Matoševu je djelu riječ o personalnome pripovjedaču koji opisuje događaje bez prisutnosti svoje osobnosti, u trećemu licu. Koegzistiranje pripovjedača i glavnoga lika razabire na primjeru Milinovićeva dnevničkog zapisa: „Danas me samoća tištala više nego ikad. Bolestan sam. Bulaznim“ (Matoš, 1935: 110). Pripovjedač je ekstradijegetski i homodijegetski, dok se subjektivizacijom (kao što je slučaj dnevničkoga zapisa) svoje pozicije dijelom transformira u homodijegetskoga. Pripovjedač je u Poeovoj noveli homodijegetski i intradijegetski s obzirom na njegovu istovjetnost s glavnim likom u vidu iznošenja priče, strahova i razmišljanja. Obje su novele obilježene jednom fabularnom linijom, a semantičke su jedinice povezane uzročno-posljedičnim vezama.

\section{Zaključak}

S obzirom na predočene najvažnije postavke simbolizma i fantastične književnosti, kao i osobitosti poetika Antuna Gustava Matoša i Edgara Allana Poea, zaključuje se kako je Poeov književno-kritičarski rad utjecao na Matoševe književne preokupacije. Dio Matoševa proznog stvaralaštva odražava poetiku simbolizma. Poeovo djelovanje kronološki pripada razdoblju romantizma, no apsolutiziranjem sebstva i uporabom simbola otvorenost njegove stvaralačke misli nadilazi tu granicu. Originalnost se njegova rada razabire u kontekstu zadiranja u teme koje su izvan granica racionalnoga. Iako i Poe upotrebljava ukrasne pridjeve s ciljem stvaranja dojma kićenosti, može se reći kako je na Matoševu primjeru o lirizaciji diskursa moguće promišljati kao o zasebnim poetskim kategorijama. U kontekstu promatranih djela razvidne su sličnosti unutar podjele motiva i odabira motivacijskih vrsta. Najvažnija je sličnost činjenica da se u objema novelama javlja rascjep između sna i jave, što se konačno sjedinjuje u smrti. S obzirom na to može se zaključiti kako je Poe polučio razvidan utjecaj na Matoševo stvaralaštvo u okvirima 
njegove simbolističke proze s elementima fantastike i groteske. Stoga se njegovo djelo može smatrati bitnim za cjelokupnu hrvatsku književnost modernizma, čiji je osobiti predstavnik upravo Matoš.

\section{Izvori}

- Matoš, Antun Gustav (1935) „Miš“, Iverje; Novo iverje, BARAC, Antun (ur.) Binoza, Zagreb

- Poe, Edgar Allan (1985) Crni mačak, Bašıć, Sonja (ur.) Školska knjiga, Zagreb

\section{Literatura}

- BAŠIĆ, Sonja (1985) „Pisac neobuzdane mašte i hladne logike“, Crni mačak, BAšıć, Sonja (ur.), Školska knjiga, Zagreb

- BEZIĆ, ŽIvAN (1989) „Moderna i postmoderna“, Obnovljeni život, Zagreb, Filozofsko teološki institut Družbe Isusove, god. XLIV, br. 2, str. 155-164.

- Biti, Vladimir (2002) Suvremena teorija pripovijedanja, Globus, Zagreb

- Cunliffe, Marcus (1979) The Literature of The United States, Penguin Books Great Britain, Suffolk

- Frangeš, Ivo (1974) Matoš, Vidrić, Krleža, Liber, Zagreb

- Freud, Sigmund (2010) Pojam jeze u književnosti i psihologiji, Scarabeus-naklada, Zagreb

- Milanja, Cvjetko (2010) Hrvatsko pjesništvo 1900 - 1950, Altagama, Zagreb

- Novak, Slobodan Prosperov (2004) Povijest hrvatske književnosti (između Pešte, Beča i Beograda), Marjan tisak, Split

- Oraić Tolić, Dubravka (1996) Lirika i proza Antuna Gustava Matoša, Školska knjiga, Zagreb 
- Smith, Guy (1970) American literature, Littlefield, Adams\&Co, Totowa, NJ.

- Todorov, Cvetan (1987) Uvod u fantastičnu književnost, Edicija Pečat, Beograd

- Tomaševski, Boris (1998) Teorija književnosti, Matica hrvatska, Zagreb

- Wilson, Edmond (1964) Akselov zamak ili o simbolizmu, Kultura, Beograd 


\title{
COMPARATIVE ANALYSIS OF THE PROSE BY EDGAR ALLAN POE AND ANTUN GUSTAV MATOS IN THE CONTEXT OF SHORT STORIES CRNI MACAK AND MIS
}

\begin{abstract}
Antun Gustav Matos is one of the most significant writers of the Croatian Literary Modernism. Part of his literary work reflects the influence of symbolism where he paid special attention to the ways of solving ontological crisis. Besides prevailing symbolism motives, one part of his short stories also contains elements of fantastic prose genre. Edgar Allan Poe was a famous literate who was writing during the age of Romantic style. His works contain elements of fantastic genre with especially emphasized feelings of creeps. Because of that, he is recognized as a forerunner of symbolism. Matos was familiar with literary and theoretical work by Edgar Allan Poe. That is especially evident in the context of symbolism prose by Matos. The aim of this paper is to prove the influence of Edgar Allan Poe on the prose by Antun Gustav Matos, referring to the most important theoretical foundations of symbolism as well as particularities of these two authors' poetics. Thus the paper will analyze short stories Mis (1899) and Crni macak (1849) taking into consideration motivation preoccupation of the two authors as well as narrative structures of the texts.
\end{abstract}

Keywords: symbolism; fantastic prose; literary modernism; motives; narrative structure 